\title{
Learning Mathematical Modelling: How to Design Visual Formed Students' Worksheets Problem
}

\author{
Dwi Oktalidiasari ${ }^{1}$, Darmawijoyo $^{2, *}$, Somakim $^{3}$
}

\begin{abstract}
${ }^{1}$ Mathematics Education Department, Sriwijaya University, Palembang, South Sumatera, Indonesia ${ }^{2}$ Mathematics Education Department, Sriwijaya University, Palembang, South Sumatera, Indonesia ${ }^{3}$ Mathematics Education Department, Sriwijaya University, Palembang, South Sumatera, Indonesia *Corresponding author.Email: darmawijoyo@unsri.ac.id
\end{abstract}

\begin{abstract}
This article discusses the development of mathematical modeling student's worksheets with the context of fuel purchase. Design research methods with a development study type was used in the research. The student's worksheet's prototype which fulfills the six principles of designing mathematical modeling questions was obtained.
\end{abstract}

Keywords: Mathematical modeling, Visual, Context, Students' Worksheet.

\section{INTRODUCTION}

The 2013 curriculum has undergone several improvements to content standards as students must think critically and analytically based on international standards by expanding relevant materials and reducing irrelevant material [1]. The development of curriculum 2013, one of which concerns is about external challenges that related to transformation in the education sector that is the participation of Indonesian students in TIMSS which shows low achievement because most of the materials tested in TIMSS are not found in the Indonesian curriculum [2].

TIMSS has two dimensions in performing assessments; those are the content dimensions and cognitive dimensions. The content dimension specifies the mathematical material to be accessed, and the cognitive dimension determines the level of thinking ability. Each of these dimensions is called a domain, namely, the content domain that accommodate numbers, geometric shapes and measures, data displays, and three cognitive domains, namely knowing, applying, and reasoning.

Indonesia has been one of TIMSS participants in the last four periods. The results of TIMSS Indonesia's 20032015 study $[3,4,5]$ are seen in the following table:
Table 1. TIMSS Indonesia Results

\begin{tabular}{c|c|c|c}
\hline Years & Scor & $\begin{array}{c}\text { Indonesia } \\
\text { Rankings }\end{array}$ & $\begin{array}{c}\text { Total Countries of } \\
\text { Participants }\end{array}$ \\
\hline 2007 & 397 & 36 & 49 \\
\hline 2011 & 386 & 38 & 42 \\
\hline 2015 & 397 & 44 & 49 \\
\hline
\end{tabular}

Based on the TIMSS criteria survey, participants' achievement is divided into four levels: advance $x \geq 625$, (high $550 \leq \mathrm{x}<625$, intermediate $400 \leq \mathrm{x}<475$, and low $x \leq 400$. If we see from the scores of TIMSS Indonesia study results in 2007, 2011, and 2015, it is still low. One of the low results is that Indonesian students are less accustomed to working on problem-solving questions [6].

In TIMSS 2015, the highest proportion of domain content was 50\%, while the highest proportion in cognitive domains was the application that is $40 \%$ [7]. While the score obtained by Indonesia in TIMSS 2015 is 397 with a low category. It means that Indonesian students only have necessary math knowledge level skills such as integer operations, solving simple story problems, simple fractions knowledge, geometric shapes 
and measurements, and reading and completing simple bar and table charts.

Some research on the analysis of the ability of Indonesian students in carrying out type questions of TIMSS from the results of his research with 134 elementary school students obtained $6.72 \%$ of students who obtained advance category, $11.94 \%$ of students in the high category, $22.39 \%$ intermediate category and $58.95 \%$ students who are low category [8]. It is evident from the study results that Indonesian students in solving questions with the level of ability in TIMSS are still low. Meanwhile, [8] stated that elementary students' ability to carry out TIMSS mathematics questions with an average score of 445 . It could be said that there are still many students at the elementary school level who still have difficulty in solving the TIMSS type of mathematics problems. One of the weaknesses of Indonesian students in working on the problem of TIMSS is not applying basic knowledge in solving problems. [9]

Today's purpose is to train students individually in solving problems by defining information and how to use information [10]. One way to achieve that goal is to use teaching materials to create an effective learning environment [11]. One of the Teaching materials that teachers can develop in the learning process is the Students' Worksheet. There are six principles of teaching materials design in developing students' worksheets, namely: 1) Some genuine links with the real world of the students 2) Opportunity to identify and specify mathematically tractable from a general problem statement; 3) Formulation of a solutions process is feasible, involving the use of mathematics accessible to students, the making of necessary assumption and the assembly of necessary data; 4) solutions of the mathematics for the fundamental problems is possible, together with interpretation; 5) An evaluation procedures that enables checking for mathematical accuracy and the appropriateness of solution with respect to the contextual setting; 6) The problem may be structured into sequential questions that retain the integrity of the real situations [12].

Innovation is needed to get used to students to change real-world problems into forms of mathematics. The situation faced differs between developing and developed countries [13]. One example of the context often encountered by students living in oil-producing countries is the purchase of vehicle fuel Fuel is a necessity that everyone needs for their vehicles to carry out their daily activities. Therefore, the researchers want to use the refueling context in determining where to refuel with the minimum amount of expenditure.

One of the approaches that help students to connect real-world problems to abstract mathematical concepts is
Mathematical Modeling. Mathematical modeling is a process of representation to get a solution to a real-world problem in the form of mathematics [14, 15]. The process of doing the mathematics of real situations in the mathematical modeling process using multiple cycles or stages of problem-solving to understand problems and identify solutions [16]. The process of mathematical modeling is in line with solving one of the topics in the cognitive domain of application in TIMSS, which is a determining topic that includes selecting operations, methods, and strategies in solving a problem. At the same time, the procedures and algorithms are already known [7].

Some researchers, $[17,18,19,20]$ stated that the application of students' worksheet mathematical modeling could also improve students' math problemsolving skills, train students' mathematical connection skills, argumentation and communication in mathematics. However, all of these studies do not provide information about the role of visual-formed problems contributing to improving students' ability to solve problems. One of the studies using image-shaped mathematics problems is [21] on looking at the effects of students' ability in the verbal representation of contextual problems in the form of images to decrease word use. So the researchers are interested in design students' worksheet mathematical modeling using mathematical problems using visuals or posters with the title "Learning Mathematical Modelling: How to Design Visual-formed Student's Worksheets Problem"

\section{RESEARCH METHODS}

This article discusses about students' worksheets problem with design research methods using a development study type [22]. Stages of design research are as follows:

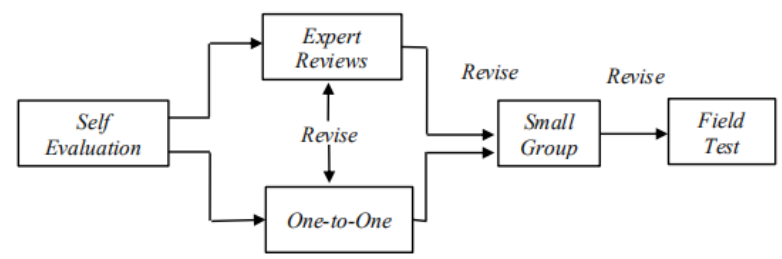

Figure 1 Formative evaluation design [23]

Based on these stages of design research, this article will discuss about the Preliminary step. At the Preliminary step, the researchers conducted the curriculum analysis, the student analysis, designing products using six principles [12]. Those are 1) some genuine links with the real world of the students; 2) Opportunity to identify and specify mathematically tractable from a general problem statement; 3) Formulation of a solutions process is feasible, involving the use of mathematics accessible to students, making a 
necessary assumption and the assembly of necessary data; 4) solutions of the mathematics for the fundamental problems is possible, together with interpretation; 5) An evaluation procedures that enables checking for mathematical accuracy and the appropriateness of solution with respect to the contextual setting; 6) The problem may be structured into sequential questions that retain the integrity of the real situations.

Furthermore, the development of mathematical modeling problems subsequently developed into a prototype of students' worksheets. In the third stage, researchers do the design with a formative evaluation.

In compiling mathematical modeling students' worksheet that makes students easier to solve a problem and facilitate them in critical thinking, researchers used six stages of mathematical modeling according to [24] (Figure 2) namely: 1) identifying and determining the problem to solve, 2) make an assumption and determining variables, 3) doing mathematics in order to obtain a solution, 4) analyzing and assessing the model and its solutions, 5) iterate as needed to improve and extend the model, 6) apply the model and report the results.

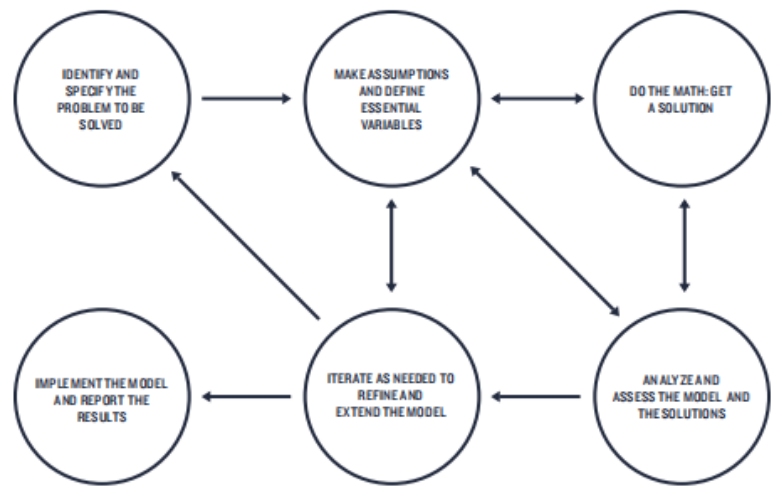

Figure 2 Mathematical Modeling Process [24]

\section{RESULTS AND DISCUSSIONS}

\subsection{Results}

\subsubsection{Analysis}

At the preliminary step or preparation, researchers conducted several stages of analysis. There are 1)TIMSS and Curriculum analysis, 2)Material analysis, 3)Student analysis.

For the first stage, researchers analyzed the revised national curriculum. As the results: It is needed to teach students from concrete problems to semi-concrete and finally abstraction of problems. Formulas handed down by students and problems submitted should be able to be worked on by students only with basic formulas and understandings. Students are asked to think critically to solve math problems. It is also needed to familiarize students to think algorithmically.

In the second stage, researchers looked at Indonesian elementary students' TIMSS scores achieved in 2007, 2011, and 2015. They are 397, 386, and 397, respectively. Based on TIMSS achievement criteria, Indonesian students always get grades below 400 or be categorized as low. It means that Indonesians students only have basic math knowledge level skills such as integer operations, solving simple story problems, knowledge of simple fractions, geometric shapes, and measurements, and can read and complete simple bar charts and tables. Whereas, when viewed from the highest proportion of TIMSS math achievement targets in 2015, the number of content domain is $50 \%$, and the cognitive domain application is $40 \%$ [7]

Based on Indonesia's achievement problems in TIMSS, in analyzing the material, researchers used mixed counting operation materials in elementary school with the ability to apply TIMSS type in the form of choosing the correct operation, method, and strategy in solving problems where the procedures, methods or algorithms to solve the problem is already known. So there is a need for habituation for Indonesian students in solving TIMSS type questions to improve students' abilities in TIMSS.

In the final stage, the researchers gave six-grade students a visual-formed problem in the form of a poster as the pretest in Pusri Primary school Palembang. It turned out that there were still students who had difficulty in understanding mathematical problems coming from pictures and graphics. They were, however, interested in doing such problems. Accordingly, it is needed innovation to help students solving visual-formed problems. One of them is the use of mathematical modeling stages.

\subsubsection{Design}

The design process of students' worksheet modeling researchers using design principles according to [12] namely: some genuine links with the real world of the students, opportunity to identify and specify mathematically tractable from a general problem statement, formulation of a solutions process is feasible, involving the use of mathematics accessible to students, the making of necessary assumption and the assembly of necessary data, solutions of the mathematics for the basic problems is possible, together with interpretation, and evaluation procedures that enables checking for mathematical accuracy and the appropriateness of solution with respect to the contextual setting, the problem may be structured into sequential questions that retain the integrity of the real situations. 


\subsection{Discussions}

\subsubsection{Design Process}

In the designing process, there are several principles of designing:

\subsubsection{First Principle}

In the first principle of dealing with students' real world, researchers chose the problem to be used in students' worksheets, which is derived from the problem in Gaimme book 2nd edition in the form of problems concerning fuel purchase.

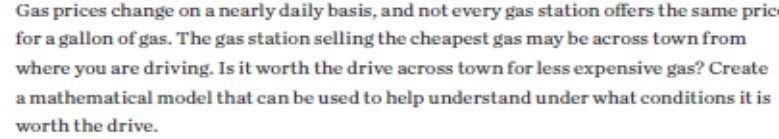

Figure 3 Fuel Purchase Problems [24]

Based on these problems, researchers do the initial design by using a problem close to students, namely the cost of purchasing fuel with a route from home to school with three refueling places with different purchase prices per liter.

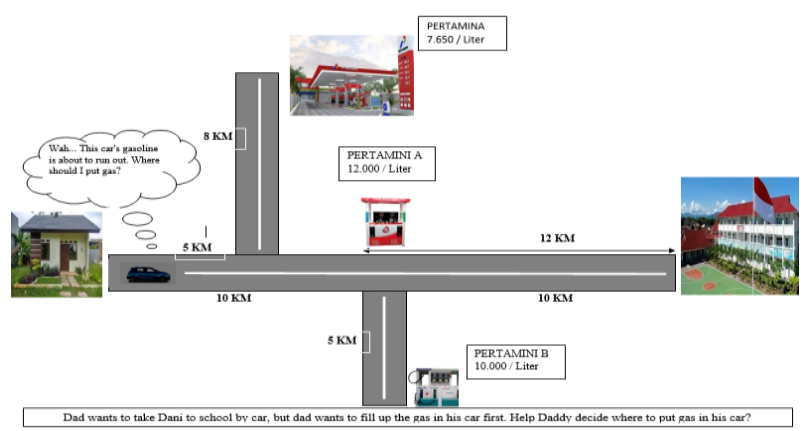

Figure 4 The initial design of prototype 1

In the initial design issue of prototype 1 , students need to consider the distance, fuel consumption, and the number of gasoline to be filled. So the results obtained by students depend on the assumption of the amount of gasoline-filled, and in the end, the student will compare the total cost incurred and determine the filling place with the minimum expense cost.

After the researchers designed the initial prototype 1, the researchers conducted a discussion panel phase in the form of Focus Group Discussion (FGD) with four master students of mathematics education using a zoom application to discuss students' worksheets being designed by researchers. At the time of the discussion, it ended up revising the initial prototype. The problem with the initial design of prototype 1 was a less real problem with the students' daily lives because usually, the distance that students take up from home to school is not up to more than $20 \mathrm{~km}$ and the map used is also not real. For the solution, it appears that the minimum cost was obtained only one conclusion, so there is an input to change the problem on students' worksheets.

From the feedback of the FGD, it is obtained the conclusion that the given problem should be relevant to the problems of daily life or problems close to students, for instance: students' trip from city A to city B with the consideration of the total minimum expenditure based on the cost of gasoline filling, distance and toll price. From the FGD's day, the researchers conducted the next design.

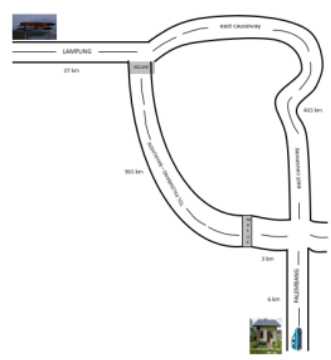
Dani and his family plan to take a vacation to Kedu Kalianda Beach in Lampung by using a private vehicle. Help Dani
and his family choose which route to take to get to Kedu Kalianda Beach in order to minimize expenses during the trip?

Figure 5 Prototype final design 1

Prototype 1 is from students' close problem in the form of a trip route to Lampung's tourist attractions, Kedu Kalianda Beach. Students are required to determine the minimum outlying cost of refueling, distance, and tolls expense on this problem. The data in the form of the distance used is the original data that the researcher got from the road sketch data across Sumatra so that the problems given include problems that exist in the students' real world.

\subsubsection{Second Principle}

On the second principle, there is an opportunity to identify and determine questions that can be mathematically resolved from common problems. Researchers visualized mathematics problems given to reduce the words' use to make it easier for students to identify the already known elements and determine the questions about the given problem.

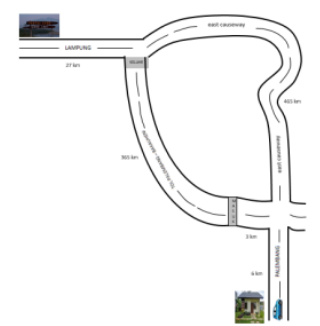

Figure 6 Problems in the form of posters

\subsubsection{Third Principle}

The third principle is formulating solutions easily and involving the use of mathematics accessible to students, 
making assumptions, and collecting given data. In the process of formulating solutions, researchers use deep modeling stages [15] that consist of: identifying the problems, making assumptions and identifying variables, do the Math, analyzing and assessing solutions, evaluating, and applying the model.

\subsubsection{Fourth Principle}

The fourth principle is the mathematical solution of the basic problem along with the achievement. In solving the problem using the modeling step, the students are expected to solve the problem by producing different answers according to their assumptions.

\subsubsection{Fifth Principle}

The fifth principle is an evaluation procedure that allows examining the mathematical accuracy and suitability of contextual solutions. In completing the study, students use the modeling stage to make learning more meaningful and fit for learning purposes.

\subsubsection{Sixth Principle}

In the sixth principle, the problem could be structured into sequential questions that show the integrated-real situation. In LKPD, researchers have designed using sequential questions and showing integrated-real situations in solving problems given to make learning more targeted and facilitate students in solving problems

\section{CONCLUSION}

Based on the design principle criteria [12] and the preliminary process that has been done by researchers, it was concluded that the designed student's worksheet had met the standard criteria of teaching materials. It means that the designed students' worksheet can continue into the evaluation step.

\section{REFERENCES}

[1] Kemendikbud, Modul penyusunan higher order thinking skill (HOTS). Jakarta: Direktorat Jenderal Pendidikan Dasar dan Menengah Departeman Pendidikan dan Kebudayaan, 2017.

[2] Permendikbud Republik Indonesia Nomor 69, Kerangka Dasar dan Struktur Kurikulum Sekolah Menengah Atas/Madrasah Aliyah, 2013.

[3] I.V.S. Mullis, M.O. Martin, P. Foy, TIMSS 2007 International mathematics report, TIMSS and PIRLS International Study Center, Lynch School of Education, Boston College, 2008.
[4] I.V.S. Mullis, M.O. Martin, P. Foy, A. Arora, TIMSS 2011 International results in mathematics, TIMSS and PIRLS International Study Center, Lynch School of Education, Boston College Chestnut Hill, MA, USA and IEA, 2012.

[5] I.V.S. Mullis, M.O. Martin, P. Foy, M. Hooper, TIMSS 2015 International results in mathematics, TIMSS and PIRLS International Study Center Lynch School of Education, Boston College and IEA, 2016.

[6] A. Tjalla, Potret mutu pendidikan indonesia ditinjau dari hasil-hasil studi internasional, Seminar Nasional FKIP-UT. Perpustakaan Digital UT, Tangerang Selatan, 2010.

[7] I.V.S. Mullis, M.O. Martin, TIMSS 2015 Assessment frameworks. TIMSS and PIRLS International Study Center, Lynch School of Education, Boston College and IEA, 2013.

[8] G. Witri, Z.H. Putra, N. Gustina, Analisis Kemampuan Siswa Sekolah Dasar dalam Menyelesaikan Soal-soal Matematika Model The Trends For International Mathematics And Scinece Study (TIMSS) di Pekanbaru, Jurnal Primary Program Studi Pendidikan Guru Sekolah Dasar Fakultas Keguruan dan Ilmu Pendidikan Universitas Riau, vol. 3, 2014, pp. 32-39.

[9] D.W. Sari, Karakteristik Soal TIMSS, Jurnal Pendidikan Matematika Universitas Negeri Yogyakarta, 2015, pp. 303-308.

[10] H. Kazu, E. Yesilyurt, Ögretmenlerin ögretim araç Gereçlerini Kullanım Amaçları [Intentions to use the teachers' teaching tools], Frrat Üniversitesi Sosyal Bilimler Dergisi, vol. 18, 2008, pp. 175188.

[11] T. Koparan, Analysis of Teaching Materials Developed by Prospective Mathematics Teachers and Their Views on Material Development, Malaysian Online Journal of Educational Technology, special issue vol. 4, 2017, pp. 8-28.

[12] C. Paolucci, H. Wessels, An examination of preservice teachers' capacity to create mathematical modeling problems for children, Journal of Teacher Education, vol. 68, 2017, pp. 330 - 344.

[13] T. Ikeda, Didactical Reflections on the teaching of mathematical modelling Suggestions from eoncepts of "time" and "place", Mathematical applications and modelling in the teuching and learning of mathematic, vol. 38, 2008, pp. 217. 
[14] L.S. Tan, K.C. Ang, A school-based professional development programme for teachers of mathematical modelling in Singapore, Journal of Mathematics Teacher Education, vol. 19, 2016, pp. 399-432. DOI: http://doi.org/10.1007/s10857-0159305-Z.

[15]K. Bliss, J. Libertini, Guidelines for Assessment \& Instruction in Mathematical Modeling Education: What is Mathematical Modeling?. USA: Comap, Inc \& Siam. 2016.

[16] R. Lesh, H. Doerr, Beyond Constructivism, Models and Modeling Perspectives on Mathematics Problem Solving, Learning, and Teaching, Lawrence Erlbaum. Mahwah, NJ. Book Reviews. Ernst von Glasersfeld, Amherst, MA (USA), vol. 35, 2003, pp. 6. Available: http://subs.emis.de/journals/ZDM/zdm036r3.pdf

[17] F.R. Selvia, Darmawijoyo, M. Yusuf, Penerapan pembelajaran pemodelan matematika menggunakan pendekatan konstruktivisme terhadap kemampuan pemecahan masalah untuk siswa kelas VIII SMP, Aksioma Jurnal Pendidikan Matematika, vol. 3, 2014, pp. 66-74.

[18] W. Wulandari, Darmawijoyo, \& Y. Hartono, Pengaruh pendekatan pemodelan matematika terhadap kemampuan argumentasi siswa kelas VIII SMP Negeri 15 Palembang, Jurnal Pendidikan Matematika, vol. 10, 2016, pp. 111-123. DOI: https://doi.org/10.22342/jpm.10.1.3292.111- 123.

[19] P. Astuti, Y. Hartono, H. Bunayati, Indaryanti, Pengembangan LKS berbasis pendekatan pemodelan matematika untuk melatih kemampuan koneksi matematis siswa SMP kelas VIII, Jurnal Pendidikan Matematika, vol. 11, 2017, pp. 61-78. DOI: $\underline{\text { https://doi.org/10.22342/jpm.11.2.4613.61-78 }}$

[20] D.P. Sari, Darmawijoyo, B. Santoso, Pengaruh pendekatan pemodelan matematika terhadap kemampuan koneksi matematis siswa kelas VIII MTs Aisyiyah Palembang, Jurnal Pendidikan Matematika Kreatif-Inovatif, vol. 9, 2018, pp. 71-77.

DOI: http://doi.org/10.15294/kreano.v9i1.12330.

[21] K. Hoogland, B. Pepin, J.D. Koning, A. Bakker, K. Gravemeijer, Word problems versus image-rich problems: an analysis of effects of task characteristics on students' performance on contextual mathematics problems, Research in Mathematics Education, vol. 20, 2018, pp. 37-52. DOI: https://doi.org/10.1080/14794802.2017.1413414

[22] J. V. Akker, Principles and Methods of Development Research Design Approaches and
Tools in Education and Training Dordrecht: Kluwer Academic Publishers, 1999.

[23] M. Tessmer, Planning and Conducting Formative Evaluations. Improving the Quality of Education and Training. London: Kogan Page, 1993.

[24] COMAP and SIAM, GAIMME : Guidelines for Assessment \& Intruction in Mathematical Modelling Education 2nd Edition, USA: COMAP Inc and SIAM, 2019. 